\title{
THE ANTIOXIDANT DEFENSE SYSTEM OF VARROA DESTRUCTOR FACILITATES THE INFESTATION OF APIS MELLIFERA
}

\author{
Kamila Dmochowska-Ślęzak \\ Małgorzata Dmitryjuk \\ Ewa Zaobidna \\ Krystyna Żółtowska* \\ Department of Biochemistry, Faculty of Biology and Biotechnology, University of \\ Warmia and Mazury in Olsztyn, Oczapowskiego 1A, 10-719 Olsztyn, Poland \\ *Corresponding Author: k.zoltowska@uwm.edu.p \\ Received 05 February 2016; accepted 06 May 2016
}

A b s tract

Varroa destructor is a parasitic mite of the Western honey bee. The activity of five antioxidant enzymes of $\boldsymbol{V}$. destructor were analysed. Glutathione content and total antioxidant status was also evaluated. Our results suggest that antioxidant enzymes constitute the main line of defense against ROS in $V$. destructor, whereas low-molecular-weight antioxidants play a limited role in the antioxidant system of mites.

Keywords: antioxidant capacity, antioxidants, antioxidative enzymes, honey bee, Varroa destructor

\section{INTRODUCTION}

$V$. destructor is considered one of the major causes of bee-colony depopulation. This mite acts directly by consuming the brood/adult bee hemolymph, and indirectly by vectoring viruses and causing immunosuppression in bees (Wilfert et al., 2016).

Antioxidants play a significant role in parasitehost interactions (Sorci \& Faivre, 2009; Lipiński \& Żółtowska, 2005). Therefore, the aim of this study was to investigate the poorly known antioxidant defense system of $V$. destructor (parasite) for further comparison with the better described (by other authors) antioxidant potential of $A$. mellifera (host).

\section{MATERIAL AND METHODS}

Mature female mites were acquired from the capped worker brood. This was brood originating from 10 bee-colonies. Acaricides had not been used in the apiary for the two years preceding this study. The experimental material was handled and mite extracts were prepared as described by Frączek et al. (2012).

The activity of total superoxide dismutase (SOD) was determined using the SOD assay kit (Sig-
ma-Aldrich). The activity of mitochondrial SOD (MnSOD) was measured using KCN as an inhibitor for Cu/Zn SODs. The activities of catalase (CAT), peroxidase (POX), glutathione peroxidase (GPX), and glutathione peroxidase (GST), and GSH contents were determined according to the methods proposed by Farjan et al. (2014). Total antioxidant status (TAS) was measured with the Randox TAS kit. The mean values of enzyme activity and SD were calculated using Excel functions.

\section{RESULTS AND DISCUSSION}

The activity of CAT was high in comparison with the activities of the remaining antioxidant enzymes of $V$. destructor (Tab. 1). The activities of CAT, total SOD, and POX were higher in the mites than the activities reported by Farjan et al. (2014) in honeybees, thus enabling the parasite to limit damage caused by reactive oxygen species (ROS) produced in response to apian (host) cuticle wounding (Strachecka et al., 2012; Sorci \& Faivre, 2009), and therefore, facilitate the host infestation. We revealed that in $V$. destructor, MnSOD was responsible for approximately one-third of the total SOD activity, which could point to a high rate of mitochondrial 
metabolism and/or significant electron leakage in its respiratory chain (Gerson et al., 1991). Non-specific POX activity was higher than GPX activity, which indicates that POX can play a greater role in scavenging hydrogen peroxide in the Varroamites than specific GPX in honeybees (compare; Strachecka et al., 2014). The activity of GST responsible for detoxification, was three-fold lower in the mites we exam than that found by Strachecka et al., (2014) in honeybees. by Gerson et al. (1991) 25 years ago, which could point to the adaptation of the mite detoxifying system to pesticides. Pesticides affect DNA methylation in V. destructor (Strachecka et al., 2015). This means that pesticides may change the expression of the proteins, including antioxidants. Pesticide-sensitive and pesticide-resistant parasites should be analysed to confirm this hypothesis.

The antioxidant system of Varroa destructor

\begin{tabular}{ccc}
\hline No & Antioxidant & $\begin{array}{c}\text { Activity or concentration } \\
\text { (mean } \pm \mathrm{SD})\end{array}$ \\
\hline 1 & Superoxide dismutase & $20.87 \pm 0.01(\mathrm{mU} / \mathrm{mg}$ protein) \\
& SOD (total) & $7.99 \pm 0.18(\mathrm{mU} / \mathrm{mg}$ protein) \\
2 & MnSOD & $820.64 \pm 107.38(\mathrm{U} / \mathrm{mg}$ protein) \\
3 & Catalase (CAT) & $234.07 \pm 40.13(\mathrm{mU} / \mathrm{mg}$ protein) \\
4 & Peroxidases (POX) & $6.95 \pm 1.07(\mathrm{mU} / \mathrm{mg}$ protein) \\
5 & Glutathione peroxidase (GPX) & $23.78 \pm 3.35(\mathrm{mU} / \mathrm{mg}$ protein) \\
6 & Glutathione (GSH) & $0.067 \pm 0.005\left(\mathrm{mg} / 100 \mathrm{mg}\right.$ of BW $\left.{ }^{\mathrm{b}}\right)$ \\
7 & Total antioxidant status (TAS) & $1.54 \pm 0.07$ (single-electron equivalents of \\
& & Trolox $/ 100 \mathrm{mg}$ of BW) \\
\hline
\end{tabular}

$N=5$ individual samples. Each sample comprised of extracts from 200 mites, ${ }^{b}$ body weight.

Glutathione concentrations were also lower in the parasites than in $A$. mellifera examined by Farjan et al., (2014). Such a low GSH content could be responsible for low TAS values in $V$. destructor in our study. Total antioxidant status of the mite was lower than those in honeybees (Strachecka et al., 2014).

A comparison of antioxidant activities in $V$. destructor (Tab. 1) and honeybees (Farjan et al., 2014) suggests that CAT, SOD, and POX constitute the first line of the mite's defense against the host's ROS facilitating the host infestation, whereas GPX and low-molecularweight antioxidants play a limited role.

The activities of GST, esterase, and cytochrome oxidase, may be used for monitoring the pesticide resistance of $V$. destructor (Gerson et al., 1991; Strachecka et al., 2015). Glutathione transferase activity determined in our study in the Varroa mites, was higher than that reported

\section{REFERENCES}

Farjan, M., Łopieńska-Biernat, E., Lipiński, Z., Dmitryjuk, M., \& Zółtowska K. (2014). Supplementing with vitamin C the diet of honeybees (Apis mellifera carnica) parasitized with Varroa destructor. Effects on antioxidative status. Parasitology, 141, 770-776. DOl:10.1017.50031182013002126.

Frączek, R., Źółtowska, K., Lipiński, Z., \& Dmitryjuk, M. (2012). Proteolytic activity in the extracts and in the excretory/secretory products from Varroa destructor parasitic mite of honeybee. International Journal of Acarology, 38, 101-109. DOl: 10.1080/01647954.2011.610357

Gerson, U., Mozes-Koch, R., \& Cohen, E. (1991). Enzyme levels used to monitor pesticide resistance in Varroa jacobsoni. Journal of Apicultural Research, 30, 17-20.DOl:10.1080/00218839.1991.11101229 
Lipiński, Z., \& Żółtowska, K. (2005). Preliminary evidence associating oxidative stress in honey bee drone brood with Varroa destructor. Journal of Apicultural Research, 44, 126-127. D01:10.1080/002188 39.2005.11101163

Sorci, G., \& Faivre, B. (2009). Inflammation and oxidative stress in vertebrate host-parasite systems. Philosophical Transactions of the Royal Society B: Biological Sciences, 364, 71-83. DOl: 10.1098/ rstb.2008.0151

Strachecka, A., Borsuk, G., Olszewski, K., \& Paleolog, J. (2015). A new detection method for a newly revealed mechanism of pyrethroid resistance development in Varroa destructor. Parasitology Research, 174, 3999-4004. DOl: 10.1007/s00436-015-4627-4

Strachecka, A., Borsuk, G., Paleolog, J., \& Olszewski, K. (2012). Anti-pathogenic activity on the body surface of adult workers Apis mellifera. Medycyna Weterуnaryjna, 68, 290-292.

Strachecka, A., Olszewski, K., Krauze, M., Paleolog, J., Borsuk, G., Merska, M., Bajda, M., \& Chobotow, J. (2014). Coenzyme Q10 treatments influence the lifespan and key biochemical resistance systems in the honeybee, Apis mellifera. Archives of Insect Biochemistry and Physiology, 86, 165-179. DOl: 10.1002/arch.21159

Wilfert, L., Long, G., Leggett, H. C., Schmid-Hempel, P., Buttin, R., Martin, S.J. M., \& Boots, M. (2016). Deformed wing virus in a recent global epidemic in honeybees driven by Varroa mites. Science, 351, 549597. DOl: 10.1126/science.aac9976 
